This item was submitted to Loughborough's Research Repository by the author.

Items in Figshare are protected by copyright, with all rights reserved, unless otherwise indicated.

\title{
System design optimisation involving phased missions
}

PLEASE CITE THE PUBLISHED VERSION

http://www.taylorandfrancis.com/books/details/9780415485135/

\section{PUBLISHER}

(c) CRC Press (Taylor \& Francis)

\section{VERSION}

AM (Accepted Manuscript)

\section{LICENCE}

CC BY-NC-ND 4.0

\section{REPOSITORY RECORD}

Astapenko, D., and L.M. Bartlett. 2012. "System Design Optimisation Involving Phased Missions". figshare. https://hdl.handle.net/2134/9300. 
This item was submitted to Loughborough's Institutional Repository (https://dspace.lboro.ac.uk/) by the author and is made available under the following Creative Commons Licence conditions.

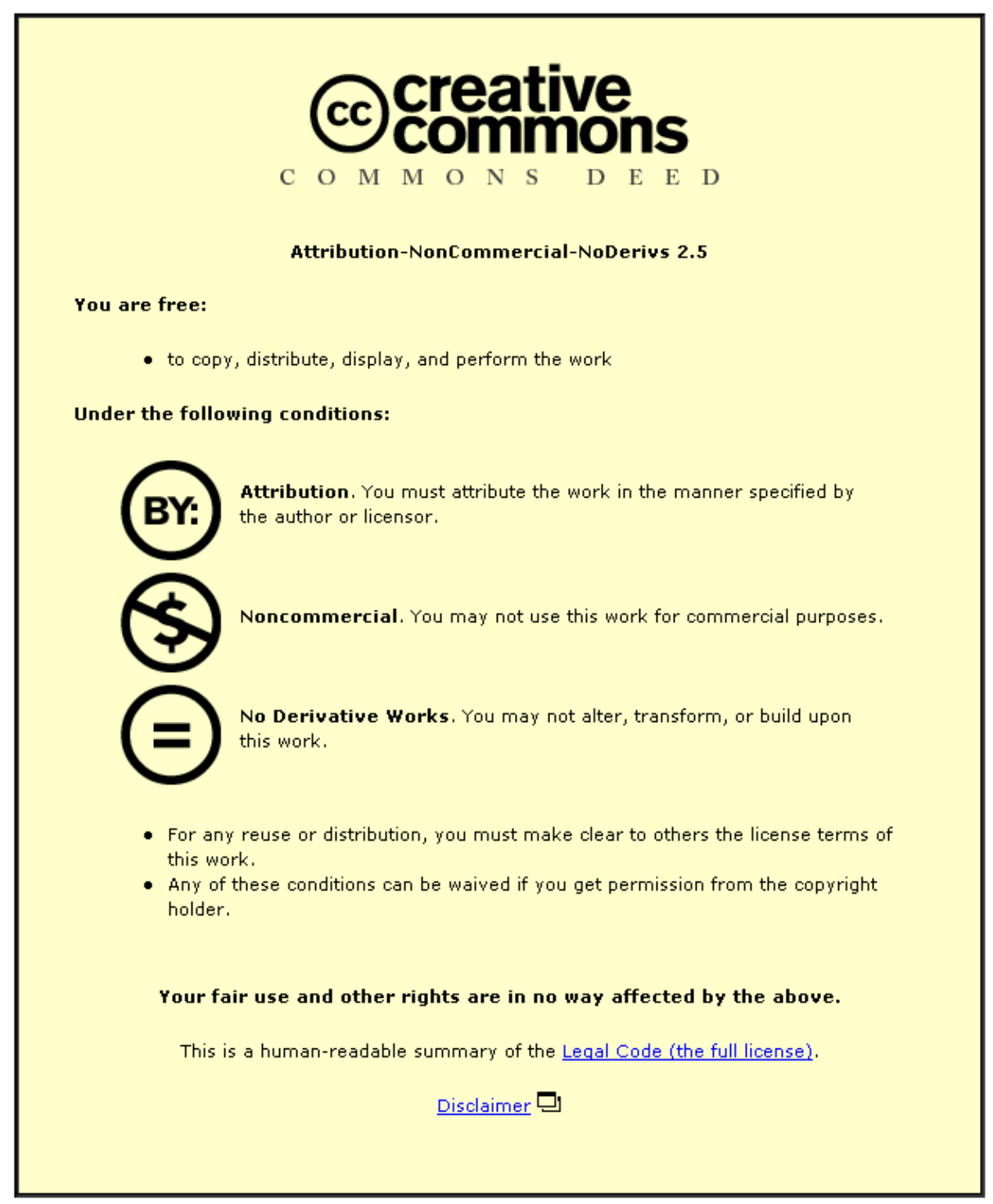

For the full text of this licence, please go to: http://creativecommons.org/licenses/by-nc-nd/2.5/ 


\title{
System design optimisation involving phased missions
}

\author{
D. Astapenko \& L.M. Bartlett \\ Department of Aeronautical and Automotive Engineering, Loughborough University, Leicestershire, UK
}

Corresponding Author: L.M.Bartlett@1boro.ac.uk

\begin{abstract}
A phased mission system represents a system where performance can be divided into consecutive non-overlapping phases. The operation of a phased mission system can be improved by introducing better performance components or adding more redundant ones. At the same time, such design alterations can influence how available resources are utilised. The focus of this paper is to develop an optimisation method to construct an optimal design case for a phased mission system to maximise its availability with optimal usage of available resources considering all phases. The developed method is based on the approach that an individual phase can be treated as a standard single phase system. Thus, to solve the whole phased mission optimisation problem each phase design is analysed individually whilst to find each phase availability value dependencies between different phases are also included in the analysis. The implemented optimisation method employs Fault Tree Analysis (FTA) to represent system performance and Binary Decision Diagrams (BDDs) are used to quantify each phase failure probability. A Single Objective Genetic Algorithm (SOGA) has been chosen as the optimisation technique. A simple military ship mission has been chosen to demonstrate the methods application. Results of the analysis are discussed.
\end{abstract}

\section{INTRODUCTION}

